\title{
Evaluation of Alternative Airway Devices in University and Educational and Research Hospital Emergency Departments in Turkey
}

\author{
Erdem Çevik', Sedat Bilge², Orhan Çınar², Yahya Ayhan Acar ${ }^{3}$, Ayşen Demir², Banu Karakuş Yılmaz ${ }^{4}$ \\ ${ }^{1}$ Clinic of Emergency Medicine, Van Military Hospital, Van, Turkey \\ 2Department of Emergency Medicine, Gülhane Military Medical Academy, Ankara, Turkey \\ ${ }^{3}$ Clinic of Emergency Medicine, Etimesgut Military Hospital, Ankara, Turkey \\ ${ }^{4}$ Department of Emergency Medicine, Bağcılar Training and Research Hospital, İstanbul, Turkey
}

\begin{abstract}
Aim: This study aims to assess the presence of alternative airway devices (AAD) in emergency departments (ED) of university and educational and research hospitals in Turkey. Thus, the instrument choices and application status and the qualifications of EDs were determined in this era.

Materials and Methods: Survey forms were sent via emails to emergency physicians who were working in university and educational and research hospitals that provided specialized training in emergency medicine. These surveys comprised questions regarding intubation frequencies, name of AADs, application status, and capnography and ventilator presence. Data were evaluated with SPSS and Medcalc statistical packet programs.

Results: Of a total of 51 hospitals that participated in this study, 47\% were university hospitals and 53\% were educational and research hospitals. The laryngeal mask airway was the most common AAD; only 13 (25.4\%) EDs stored at least one supraglottic airway, one videoscopic imaging system, and surgical airway instrument.

Conclusion: It was concluded that the rate of the presence of AAD and capnography in our EDs were low, and increasing the frequency of the presence of alternative airway devices is essential to reduce mortality and morbidity in EDs where difficult airway cases are frequently observed.

(Eurasian J Emerg Med 2015; 14: 192-6)
\end{abstract}

Keywords: Difficult airway, alternative airway device, emergency department

\section{Introduction}

Maintaining airway integrity, assuring oxygenation and ventilation, and preventing aspiration are the mainstay of emergency airway management (1). Endotracheal intubation has, unquestionably, been accepted as the gold standard method for ensuring airway patency (2-4). Unfortunately, endotracheal intubation using standard techniques fails in $1 \%-3 \%$ of patients, and in emergency departments, this ratio was observed to be $3 \%-10 \%(5-7)$. Therefore, many alternative devices that have been developed for use in difficult airway situations have been recommended to be kept available in emergency departments $(8,9)$.

Alternative airway devices can include extraglottic devices [laryngeal mask airway (LMA), intubating laryngeal mask airway (ILMA), Combitube, etc.], fiber optic systems, video laryngoscopes, and sur- gical airway equipment (10-14). Moreover, capnography (Class 1A), which has been recommended for routine use to verify the correct placement of intubation and the transport ventilators used to provide breathing after intubation, is an airway device that is required in emergency departments $(15,16)$. The Ministry of Health of Turkey has designated LMA or Esophageal Obturator Airway, Combitube, fiber optic laryngoscope, and cricothyrotomy as the minimum required alternative airway devices in a third-level emergency department (17). Furthermore, they have recommended the use of devices that can perform end-tidal $\mathrm{CO}_{2}\left(\mathrm{ETCO}_{2}\right)$ measurements in secondand third-level emergency departments.

Considering the strict airway guidelines, having at least one or preferably a few of these alternative airway devices present in emergency departments is necessary. Therefore, this study aimed to reveal the current status of alternative airway devices in emergency depart-

Correspondence to: Erdem Çevik e-mail: cevikerdem@yahoo.com

Received: 31.08.2013 Accepted: 05.12.2013

oCopyright 2015 by Emergency Physicians Association of Turkey - Available online at www.eajem.com DOI: $10.5152 /$ eajem.2015.05900 
ments of the university and training and research hospitals in Turkey. The goal was to determine the instrument choices and application status and the qualifications of emergency departments in this field.

\section{Materials and Methods}

This descriptive survey was conducted between July 2012 and January 2013 with the approval of the Gülhane Military Medical Academy Ethics Committee (protocol number 1491-280-12/1539580; March 31, 2012).

\section{Selection of participants}

After analyzing the quotas between 2008 and 2012 according to the medical specialty selection guide, approximately 78 university and training and research hospitals that provide emergency medicine education were included, with the goal of reaching emergency departments in these hospitals. Emergency medicine physicians who served in these units were accessed using personal email accounts and emergency medicine physicians' communication groups with the intention of gaining information regarding the units in which they worked.

Emergency medicine physicians in the university and training and research hospitals were selected from the email address pool of emergency physicians and assistants, and the survey forms were electronically sent. After 1 month, a reminder email was sent to non-respondents. Furthermore, emergency medicine physicians were invited to participate in the survey through a common email sent to the emergency medicine mail group because of the low number of participants who replied to personal emails. After checking the names of the institutions in the survey, only the first application of any repeated participation from the same hospital was included in this study. Any participation from private or state hospitals was excluded because these were not target hospitals.

\section{Data collection tools}

The prepared survey comprised nine questions, with one open-ended question (issues not covered by preceding questions). The questions in the survey comprised the following:

a) Institution in which they work,

b) Number of intubations per month,

c) Names of airway devices available in their emergency departments,

d) Application status of airway devices available in their emergency departments,

e) Reasons for not using available devices,

f) Availability and application status of a surgical cricothyrotomy set,

g) Availability and application status of a percutaneous cricothyrotomy set,

h) Availability and application status of a capnography/capnometer,

i) Availability and application status of a transport ventilator.

\section{Statistical analysis}

The frequency and percentage were used for the categorical variables in the descriptive analysis. In addition, the Chi-square test was used to compare the results according to the type of hospital.
For the statistical data analysis, Statistical Package for the Social Sciences 15.0 (SPSS Inc; Chicago, IL, USA) and MedCalc 11.3 (MedCalc Software, Mariakerke, Belgium) were used, and $p<0.05$ was considered to be statistically significant.

\section{Results}

Out of 1313 personal email addresses belonging to emergency medicine physicians and assistants, 320 who were known to work at the university and training and research hospitals were sent copies of the survey via personal email. Out of 72 responses, 13 were excluded from the study because they did not work at the target hospitals and eight were excluded because they were repeated participation from the same hospital. Overall, 51 emergency medicine physicians, i.e., data from 51 hospitals, were included in the study. Of the participating hospitals, 47\% $(n=24)$ were university hospitals and 57\% $(n=27)$ were training and research hospitals. The rate of intubations performed in emergency departments per month was reported to be $43.13 \%$ (between 10 and 30). There was no significant difference $(p=0.414)$ between the number of intubations performed at the university hospitals and those performed at the training and research hospitals (Table 1).

The number of emergency departments with no alternative airway devices was six (11.8\%). Overall, LMA was most often used, with a rate of $82.4 \%(n=42)$, followed by the Combitube, with a rate of $35 \%$ $(n=18)$. This study revealed that only 4 of the hospitals had video laryngoscopes (GlideScope GVL or Storz C-MAC), and 3 had fiber optic laryngoscopes, out of the 51 hospitals in which the systems based on the imaging methods were not yet common. Airtraq, with a rate of $27.5 \%$ ( $n=14$ ), was remarkably the most commonly found system based on imaging methods (Table 2 ). In addition, $62.7 \%$ of hospitals did not have surgery sets, whereas $51 \%(n=26)$ did not have percutaneous cricothyrotomy sets. Moreover, there was no capnography in $57 \%(n=29)$ of hospitals, whereas transport ventilators were reported as relatively common, and they were available in emergency departments at a rate of $72.5 \%(n=37)$ (Table 3 ). The number of emergency departments that stored at least one supraglottic airway, one imaging system, and surgical airway devices was only 13 (25.4\%). Finally, it was reported that the available but unused devices in emergency departments was $88 \%$.

On the basis of these results, it was concluded that there were no significant differences between the university and training and research hospitals in terms of their devices. Table 2 shows the alternative airway device distribution by hospital, while Table 3 shows the distribution of the other materials associated with the airway and

Table 1. The number of intubations of hospitals

\begin{tabular}{|l|c|c|}
\hline $\begin{array}{l}\text { Number of Intubations } \\
\text { per month }\end{array}$ & University Hospital & $\begin{array}{c}\text { Training and } \\
\text { Research Hospital }\end{array}$ \\
\hline$<10$ & $8(33.3)$ & $5(18.5)$ \\
\hline $10-30$ & $9(37.5)$ & $13(48.2)$ \\
\hline $31-60$ & $3(12.5)$ & $5(18.5)$ \\
\hline $61-100$ & $3(12.5)$ & $2(7.4)$ \\
\hline$>100$ & $1(4.2)$ & $2(7.4)$ \\
\hline$p=0.414$ & & \\
\hline
\end{tabular}


their application status. Finally, there was no statistically significant difference in the rates of availability of devices in terms of the hospital ( $p>0.05)$.

\section{Discussion}

This study revealed that $11.8 \%$ of the university and training and research hospitals in our country do not have alternative airway devices and that the number of emergency departments that have optimal alternative airway devices (as identified by the Ministry of Health in Turkey) is $13 \%$. Moreover, it was revealed that capnography was found in less than half of the emergency departments. These results are based on the assumption that the university and training and research hospitals are better equipped and that the alternative airway device supply in emergency departments across the country is likely to be even more inadequate. Although they are regulated by law, when the causes for inadequate alternative airway devices in emergency departments are considered, the first problem is the difficulties encountered in obtaining the devices.

Difficult airway management is a basic educational field in emergency medicine residency training, and alternative airway de-

Table 2. Alternative airway device distribution by hospitals

\begin{tabular}{|l|c|c|c|}
\hline $\begin{array}{l}\text { Alternative } \\
\text { airway } \\
\text { devices }\end{array}$ & $\begin{array}{c}\text { University } \\
\text { Hospital }\end{array}$ & $\begin{array}{c}\text { Training and } \\
\text { Research } \\
\text { Hospital }\end{array}$ & Total \\
\hline LMA & $19(79.1)$ & $23(85.1)$ & $42(82.4)$ \\
\hline ILMA & $8(33.3)$ & $5(18.5)$ & $13(25.5)$ \\
\hline Combitube & $9(37.5)$ & $9(33.3)$ & $18(35.3)$ \\
\hline Airtraq & $7(29.1)$ & $7(25.9)$ & $14(27.5)$ \\
\hline Videolaryngoscope & $4(16.6)$ & 0 & $4(7.8)$ \\
\hline $\begin{array}{l}\text { Fiberoptic } \\
\text { laryngoscope }\end{array}$ & $1(4.1)$ & $2(7.4)$ & $3(5.9)$ \\
\hline TT Jet ventilator & $7(29.1)$ & $4(14.8)$ & $11(21.6)$ \\
\hline Lighted stylet & $3(12.5)$ & $6(22.2)$ & $9(17.6)$ \\
\hline Retrograde intubation & $3(12.5)$ & $1(3.7)$ & $4(7.8)$ \\
\hline LMA: Laryngeal Mask Airway; ILMA: Intubating Laryngeal Mask Airway \\
\hline
\end{tabular}

vice courses are offered in many training sessions and meetings. The importance of these alternative devices has increased in basic emergency practice, such as in rapid-sequence intubation, particularly in which a patient's respiration is stopped by the doctor. Therefore, it is not likely that emergency medicine physicians do not recognize these devices or do not believe that these devices are required in emergency departments.

This study revealed that LMA is preferred, which may be because of factors such as its many years of use or its price advantage over other imaging systems. LMA is an effective alternative in cases of difficult intubation, airway masses, or vocal cords that cannot be displayed because of cervical pathologies $(18,19)$. In addition, when using LMA, successful ventilation during cardiopulmonary resuscitation was reported in $72 \%-97 \%$ of patients $(20-24)$. In the USA, LMA is available as an alternative method in crash carts that have airway devices, at a rate of $80 \%$, which is similar to this study (25). However, LMA causes some complications, such as partial or complete airway obstruction, and it is inadequate for protection against the aspiration of gastric contents (1). ILMA was designed to perform both extraglottic ventilation and endotracheal intubation (26). Many authors, with regard to the study results, have recommended ILMA for airway management in emergency departments and outside the hospital (27-29). ILMA provides an intubation success rate of $100 \%$ when used by experienced anesthetists under operating conditions (30). In addition, Cinar et al. (31) reported that the intubation success rate was $92.6 \%$ in a study of paramedics that had not used ILMA before. Studies of esophageal-tracheal Combitubes in in-hospital and out-of-hospital resuscitations have demonstrated that rescuers with different education levels can use the Combitube and that it provides ventilation at the same level as endotracheal intubation (32-36). A successful ventilation rate of $62 \%-100 \%$ has been reported during cardiopulmonary resuscitation with the use of the Combitube. For medical personnels who do not have enough airway experience, in either pre-hospital situations or emergency departments, the use of extraglottic airway devices that provide high ventilation is recommended; however, this study revealed that the presence of these devices is low in our hospitals.

Martin et al. (7) reported rates of $50 \%$ for the elastic plug and $48 \%$ for video-assisted devices as alternative airway devices in the USA. Indirect optical systems (Airtraq) and video-assisted systems (GVL, fiber optic laryngoscope, and C-MAC) provide much better

Table 3. Distribution of other materials associated with airway by hospitals

\begin{tabular}{|c|c|c|c|c|c|}
\hline & & $\begin{array}{c}\text { Surgical } \\
\text { cricothyrotomy }\end{array}$ & $\begin{array}{l}\text { Percutaneous } \\
\text { cricothyrotomy }\end{array}$ & Capnography & $\begin{array}{l}\text { Transport } \\
\text { ventilator }\end{array}$ \\
\hline \multirow[t]{2}{*}{ University Hospital } & Not available & $13(54.2)$ & $10(41.7)$ & $12(50)$ & $5(20.8)$ \\
\hline & Available but not in use & $5(20.8)$ & $4(16.6)$ & $0(0)$ & $1(4.2)$ \\
\hline \multirow{2}{*}{$\begin{array}{l}\text { Training and } \\
\text { Research Hospital }\end{array}$} & Not available & $19(70.4)$ & $16(59.3)$ & $17(63)$ & $9(33.3)$ \\
\hline & Available but not in use & $5(18.5)$ & $7(25.9)$ & $0(0)$ & $2(7.4)$ \\
\hline \multirow[t]{3}{*}{ Total } & Not available & $32(62.7)$ & $26(51)$ & $29(56.9)$ & $14(27.5)$ \\
\hline & Available and in use & $9(17.6)$ & $14(27.5)$ & $22(43.1)$ & $34(66.7)$ \\
\hline & Available but not in use & $10(19.6)$ & $11(21.6)$ & $0(0)$ & $3(5.9)$ \\
\hline
\end{tabular}


glottic views than the direct laryngoscope, revealing a high intubation success rate in patients with difficult airway (37-39). While the intubation success rate for GVL has been demonstrated to be $90 \%-92 \%$ in previous studies, the intubation success rates for GVL and ILMA were demonstrated to be close at over 90\% in Cinar et al.'s study (31). One study that compared GVL, C-MAC, and direct laryngoscopy emphasized that the video laryngoscope provided a better glottic view; the intubation failure rates were $0 \%$ in C-MAC, $3 \%$ in GVL, and $7 \%$ in direct laryngoscopy, whereas the intubation time was shorter in C-MAC. The shorter intubation time has been attributed to the similarity between this device and the direct laryngoscope (40). In another study that compared GVL and Airtraq, both were reported as performing successful intubation without the requirement for cervical mobilization; however, the intubation time with Airtraq was shorter (41). Although numerous advantages of using these systems in emergency departments have been reported, it is worth noting that only a few hospitals use them in our country. The limited use of these devices in our hospitals may be because their widespread use has been described only in recent years and their high prices.

The requirement for a surgical airway intervention after unsuccessful intubation is approximately $0.8 \%$, and this rate increases to $11 \%$ in pre-hospital intubation $(42,43)$. Percutaneous cricothyrotomy using the Seldinger technique is faster when compared with surgical cricothyrotomy, and the success rates of each technique range from $60 \%$ to $100 \%$ (43). The surgical and percutaneous cricothyrotomy equipments used in rescue methods, when ventilation and oxygenation cannot be provided, are available in emergency departments of our hospitals at the rate of $50 \%$. However, some of these equipments are not required because other methods are used. This deficiency is more pronounced, particularly in the training hospitals. Morton et al.'s (44) study of emergency departments revealed that $98 \%$ had surgical airway devices, whereas $89 \%$ held one or more alternative devices. Our study has revealed that $88.3 \%$ of emergency departments had one or more alternative devices; however, the number of hospitals that had minimum airway devices (as determined by the Ministry of Health) remained at 13 (25.4\%), which is very low.

Esophageal intubation is a frequently encountered problem in emergency medicine, and the frequency of esophageal intubation has been increasing because of pre-hospital interventions, pediatric patients, and inexperienced personnel (45). In retrospective studies, endotracheal intubation has been associated with a $6 \%-25 \%$ incidence of unrecognized tube misplacement or displacement (16). In 2011, the American College of Emergency Physicians announced that the measurement of ETCO 2 is the most accurate and easily applicable method for verifying and monitoring patients with adequate tissue perfusion (45). In 2010, the American Heart Association Guidelines for Resuscitation reported that, in addition to clinical assessment, capnography was the most reliable method of confirming endotracheal intubation (16,45). In addition, Silvestri et al. (46) demonstrated that esophageal intubation decreased from $23 \%$ to $0 \%$ with the use of capnography for the verification of endotracheal tube placement. In one survey, emergency departments in the UK were reported to have capnography at rates of $74 \%$ (44). Although capnography is a required device that must be available in all third-level emergency departments, in our study, it was observed to be present in only $44 \%$ of emergency departments. The low rate of the availability of capnography that is used for end-tidal $\mathrm{CO}_{2}$ measurements, which is the gold standard for the verification of intubation and monitoring, is a serious deficiency in our emergency departments. Overcoming this shortcoming will bring substantial benefits for patient management.

\section{Study limitations}

The most important limitations of this study were the inclusion of only the hospitals that provide emergency medicine training and the inability to reach all of those hospitals. In addition, there were limitations in the electronic transmission of the surveys, which might be prevented with face-to-face interviews.

\section{Conclusion}

This study concluded that alternative airway devices and capnography in our emergency departments are available at low rates and that most of our hospitals do not have the minimum airway devices that are determined by the Ministry of Health. It has been concluded that alternative airway devices in emergency departments for frequently encountered difficult airway cases must be present to reduce mortality and morbidity.

Ethics Committee Approval: Ethics committee approval was received for this study from the ethics committee of Gülhane Military Medical Academy (protocol number 1491-280-12/1539-580; March 31, 2012).

Informed Consent: Questions sent to emergency medicine physicians mail address and answer of partisipants who agreed to participate the study was included.

Peer-review: Externally peer-reviewed.

Conflict of Interest: No conflict of interest was declared by the authors.

Financial Disclosure: The authors declared that this study has received no financial support.

\section{References}

1. Danzl DF, Vissers RJ. Tracheal intubation and mechanical ventilation. In: Tintinalli JE, editor. Emergency medicine: a comprehensive study guide. New York: McGraw-Hill; 2010. p. 480-506.

2. Celiker V, Basgul E. Pre-hospital airway management in trauma. Ulus Travma Acil Cerrahi Derg 2005; 11: 89-95.

3. American College of Surgeons. Advanced Trauma Life Support for Doctors, 6th edn. Chicago: American College of Surgeons, 1997.

4. Young KK, Oh TE. Airway management. In: Oh TE, ed. Intensive Care Manual. Oxford: Butterworth-Heinemann 1997; 217-27.

5. Tayal VS, Riggs RW, Marx JA, Tomaszewski CA, Schneider RE. Rapid-sequence intubation at an emergency medicine residency: success rate and adverse events during a two-year period. Acad Emerg Med 1999; 6: 31-7. [CrossRef]

6. Sakles JC, Laurin EG, Rantapaa AA, Panacek EA. Airway management in the emergency department: a one-year study of 610 tracheal intubations. Ann Emerg Med 1998; 31: 325-32. [CrossRef]

7. Martin LD, Mhyre JM, Shanks AM, Tremper KK, Kheterpal S. 3,423 Emergency tracheal intubations at a University Hospital. Airway outcomes and complications. Anesthesiology 2011; 114: 42-8. [CrossRef]

8. American Society of Anesthesiologists Task Force on Management of the Difficult Airway. Practice guidelines for management of the difficult airway: a report. Anesthesiology 1993; 78: 597-602. [CrossRef]

9. European Resuscitation Council. Guidelines for the advanced management of the airway and ventilation during resuscitation. Resuscitation 1996; 31: 201-30. [CrossRef] 
10. Ferson DZ, Rosenblatt WH, Johansen MJ, Osborn I, Ovassapian A. Use of the intubating LMA Fastrach in 254 patients with difficult-to-manage airways. Anesthesiology 2001; 95: 1175-81. [CrossRef]

11. Frappier J, Guenoun T, Journois D, Philippe H, Aka E, Cadi P, et al. Airway management using the intubating laryngeal mask airway for the morbidly obese patient. Anesth Analg 2003; 96: 1510-5. [CrossRef]

12. Niforopoulou P, Pantazopoulos I, Demesthia T, Koudouna E, Xanthos T. Video-laryngoscopes in the adult airway management: a topical review of the literature. Acta Anaesthesiol Scand 2010; 54: 1050-61. [CrossRef]

13. Ahmed-Nusrath A. Videolaryngoscopy. Curr Anaesth Crit Care 2010; 21: 199-205. [CrossRef]

14. Behringer EC, Kristensen MS. Evidence for benefit vs. novelty in new intubation equipment. Anaesthesia 2011; 66(Suppl 2): 57-64. [CrossRef]

15. Silvestri S, Ralls GA, Krauss B, Thundiyil J, Rothrock SG, Senn A, et al. The effectiveness of out-of-hospital use of continuous end-tidal carbon dioxide monitoring on the rate of unrecognized misplaced intubation within a regional emergency medical services system. Ann Emerg Med 2005; 45: 497-503. [CrossRef]

16. AHA Guidline. 2010 International Consensus on Cardiopulmonary Resuscitation and Emergency Cardiovascular Care Science With Treatment Recommendations. Circulation. 2010; 122(Suppl 2): 729-67.

17. Yataklı sağlık tesislerinde acil servis hizmetlerinin uygulama usul ve esasları hakkında tebliğ. TC Resmi Gazete, 27378, 16 Ekim 2009.

18. Calder I, Ordman AJ, Jackowski A, Crockard HA. The Brain laryngeal mask airway. An alternative to emergency tracheal intubation. Anaesthesia 1990; 45: 137-9. [CrossRef]

19. Reinhart DJ, Simmons G. Comparison of placement of laryngeal mask airway with endotracheal tube by paramedics and respiratory therapists. Ann Emerg Med 1994; 24: 260-3. [CrossRef]

20. Tobias JD, Mencio GA, Atwood R, Gurwitz GS. Intraoperative cardiopulmonary resuscitation in the prone position. J Pediatr Surg 1994; 29: 1537-8. [CrossRef]

21. Brown J, Rogers J, Soar J. Cardiac arrest during surgery and ventilation in the prone position: a case report and systematic review. Resuscitation 2001; 50: 233-8. [CrossRef]

22. Zeh E, Rahner E. The manual extrathoracal stimulation of the heart. Technique and effect of the precordial thump (author's transl). Z Kardiol 1978; 67: 299-304.

23. Weiss SJ, Ernst AA, Jones R, Ong M, Filbrun T, Augustin C, et al. Automatic transport ventilator versus bag valve in the EMS setting: a prospective, randomized trial. South Med J 2005; 98: 970-6. [CrossRef]

24. Johannigman JA, Branson RD, Johnson DJ, Davis K Jr, Hurst JM. Out-of-hospital ventilation: bag-valve device vs transport ventilator. Acad Emerg Med 1995; 2: 719-24. [CrossRef]

25. Niven AS, Doerschug KC. Techniques for the difficult airway. Curr Opin Crit Care 2013; 19: 9-15. [CrossRef]

26. Brain Al, Verghese $\mathrm{C}$, Addy EV, Kapila A. The intubating laryngeal mask. I: development of a new device for intubation of the trachea. Br J Anaesth 1997; 79: 699-703. [CrossRef]

27. Dorges V, Wenzel V, Neubert E, Schmucker P. Emergency airway management by intensive care unit nurses with the intubating laryngeal mask airway and the laryngeal tube. Crit Care 2000; 4: 369-76. [CrossRef]

28. Rosenblatt $\mathrm{WH}$, Murphy $\mathrm{M}$. The intubating laryngeal mask: use of a new ventilating-intubating device in the emergency department. Ann Emerg Med 1999; 33: 234-8. [CrossRef]
29. Young B. The intubating laryngeal-mask airway may be an ideal device for airway control in the rural trauma patient. Am J Emerg Med 2003; 21 : 80-5. [CrossRef]

30. Ferson DZ, Rosenblatt WH, Johansen MJ, Osborn I, Ovassapian A. Use of the intubating LMA-Fastrach in 254 patients with difficult-to-manage airways. Anesthesiology 2001; 95: 1175-81. [CrossRef]

31. Cinar O, Cevik E, Yildirim AO, Yasar M, Kilic E, Comert B. Comparison of GlideScope video laryngoscope and intubating laryngeal mask airway with direct laryngoscopy for endotracheal intubation. Eur J Emerg Med 2011; 18: 117-20. [CrossRef]

32. Sun WZ, Huang FY, Kung KL, Fan SZ, Chen TL. Successful cardiopulmonary resuscitation of two patients in the prone position using reversed precordial compression. Anesthesiology 1992; 77: 202-4. [CrossRef]

33. Amir O, Schliamser JE, Nemer S, Arie M. Ineffectiveness of precordial thump for cardioversion of malignant ventricular tachyarrhythmias. Pacing Clin Electrophysiol 2007; 30: 153-6. [CrossRef]

34. Haman L, Parizek P, Vojacek J. Precordial thump efficacy in termination of induced ventricular arrhythmias. Resuscitation 2009; 80: 14-6. [CrossRef]

35. Ahmar W, Morley P, Marasco S, Chan W, Aggarwal A. Sternal fracture and osteomyelitis: an unusual complication of a precordial thump. Resuscitation 2007; 75: 540-2. [CrossRef]

36. Miller J, Tresch D, Horwitz L, Thompson BM, Aprahamian C, Darin JC. The precordial thump. Ann Emerg Med 1984; 13: 791-4. [CrossRef]

37. Noppens RR, Mobus S, Heid F, Schmidtmann I, Werner C, Piepho T. Evaluation of the McGrath Series 5 videolaryngoscope after failed direct laryngoscopy. Anaesthesia 2010; 65: 716-20. [CrossRef]

38. Noppens RR, Geimer S, Eisle N, David M, Piepho T. Endotracheal intubation using the C-MAC(R) video laryngoscope or the Macintosh laryngoscope: a prospective, comparative study in the ICU. Crit Care 2012; 16: R103. [CrossRef]

39. Mosier JM, Stolz U, Chiu S, Sakles JC. Difficult airway management in the emergency department: Glidescope videolaryngoscopy compared to direct laryngoscopy. J Emerg Med 2012; 42: 629-34. [CrossRef]

40. Healy DW, Picton P, Morris M, Turner C. Comparison of the glidescope, CMAC, storz DCl with the Macintosh laryngoscope during simulated difficult laryngoscopy: a manikin study. BMC Anesthesiol 2012; 12: 11. [CrossRef]

41. Amathieu R, Sudrial J, Abdi W, Luis D, Hahouache H, Combes X, et al. Simulating face-to-face tracheal intubation of a trapped patient: a randomized comparison of the LMA Fastrach\&trade; the GlideScope\&trade; and the Airtraq\&trade; laryngoscope. Br J Anaesth 2012; 108: 140-5. [CrossRef]

42. Bair AE, Filbin MR, Kulkarnio RG, Walls RM. The failed intubation attempt in the emergency department: analysis of prevalence, rescue techniques, and personnel. J Emerg Med 2002; 23: 131-40. [CrossRef]

43. Hamaekers $A E$, Henderson JJ. Equipment and strategies for emergency tracheal access in the adult patient. Anaesthesia 2011; 66(Suppl 2): 6580. [CrossRef]

44. Morton T, Brady S, Clancy M. Difficult airway equipment in English emergency departments. Anaesthesia 2000; 55: 485-8. [CrossRef]

45. Cinar O. Capnography use in the emergency department. TATD 2011; 11: 80-9. [CrossRef]

46. Silvestri S, Ralls GA, Krauss B, Thundiyil J, Rothrock SG, Senn A, et al. The effectiveness of out-of-hospital use of continuous end-tidal carbon dioxide monitoring on the rate of unrecognized misplaced intubation within a regional emergency medical services system. Ann Emerg Med 2005; 45: 497-503. [CrossRef] 